\title{
IMPACT OF INTELLECTUAL CAPITAL ON FINANCIAL PERFORMANCE
}

\author{
Hendra Gunawan ${ }^{1)}$, Rica Tartila ${ }^{2)}$ \\ Mnagerial Accounting Departement, Politeknik Negeri Batam \\ Jl. Ahmad Yani, Batam Centre, Batam 29461, Indonesia \\ ${ }^{1)}$ E-mail: hendra@polibatam.ac.id \\ ${ }^{2)}$ E-mail: ricatartila9@gmail.com
}

\begin{abstract}
Science and emerging technology in the manufacturing industry made the importance of implementing knowladge based industries, it has focused the importance of the using intellectual capital in this industry. This study aims to analyze the impact of intellectual capital on the financial performance. The empirical data were drawn from panel consisting of 51 companies manufacturing in Indonesia Stock Exchange (IDX) from 2010-2014. Various regression models were examined in order to test the hypothesis included in the proposed conceptual framework. The result showed value added intellectual capital (VAIC), value added human capital (VAHU), structural capital value added (STVA) have significant effect with four financial performance measures ROA, ROE, GR, EVA. Meanwhile, value added capital employed (VACA) have significant effect with two dependent variable ROA,ROE and no significant effect on GR, EVA. The results of the overall analysis regression only VACA which had no effect with GR and EVA.the lack of available data for the appropriate analysis be the main limitations of this study. The result of this study can explained the role and importance of intellectual capital to improve financial performance for companies and the result of this study study also can be used by shareholders and investors.
\end{abstract}

Kata Kunci: intellectual Capital, financial performance, VAIC, Indonesia Stock Exchange (IDX)

\section{Introduction}

This last decade progressed very rapidly. The development of technology and information indirectly force the company to change its business strategy from that based on physical resources into knowledge. In order to compete and survive in the long term, the company should have a competitive advantage that can provide added value for the company.

Competitive advantage can be created by having the intellectual capital that is an asset of knowledge contained in the company. Such knowledge not only in themselves but also are employees in companies that are considered as intellectual assets that such information, patents, trademarks, manufacturing process, database, brand equity. Assets of the asset can be a foundation of core competencies that influence the development of the durability and sustainability of competitive advantage (Sangkala, 2006).
Nahapiet \& Ghoshal (2002) states that the company has the intellectual capital will be more adaptive, innovative, and responsive to changes in the demand environment. Therefore, the ownership of intellectual capital, the company will have the resources when managed effectively able to encourage companies to retain a competitive advantage compared to its competitors (Sangkala, 2006). There are many definitions of intellectual capital Edvinson \& Malon (1997) intellectual capital is the knowledge that can be converted to the value. The main objective of this study was to examine the effect of intellectual capital on the financial performance.

The continued development of the concept of intellectual capital, we need a method to be able to measure it accurately. This study uses a measurement tool intellectual capital developed by Pulic (2008) in the study stated that intellectual capital is very important to improve the efficiency of value creation that will lead to the advantages and benefits for the company. Companies need to know how to create 
value added. Assessing intellectual capital according Pulic (2008) using a measuring instrument that has been developed, namely value added intellectual coefficient (VAIC). VAIC high indicates the company's ability to manage intellectual capital to produce value-added, to create added value VAIC using three components consist of human capital which is calculated by the human capital value added (VAHU) which shows how much value added (VA) is spent on employees (wages and salaries) in the company. Structural capital is calculated using the structural capital value added (STVA) to see how big the contribution of structural capital in creating value added.

Capital employee is calculated using the value added capital employed (VACA) which is an indicator for the value added created by one unit of physical capital. In this study, the use VAIC method in researching the effect performed separately from value-added efficiency of physical capital, human capital and structural capital efficiency value added in financial performance.

\section{Theory and Development hypothesis}

The financial performance is essential for companies and stakeholders who have a diversity of interest in the company. Gutrie \& James (2001) Stake holder theory states that every stakeholder has a right to be provided information on how the company's activities in influencing stakeholders ( example through sponsorship, security initiatives, etc.) even though they will not use the information. In context on intellectual capital is an intangible asset that is if the company is able to able to utilize the full potential of the company such as human capital, employee capital and structural capital it will create value for the company that can drive a company's financial performance to stakeholders.

The strength of the key stakeholders to influence the management in the process of exploiting the potential that exists within the company. Intellectual capital is also one of the resources of the company. Resources based theory (RBT) is a theory that was developed to analyze the competitive advantage of a company which offers the advantage of knowledge or the economy that rely on intangible assets (Wijayanti, 2012). Companies are able to manage resources well in this regard is the intellectual capital that these companies will have a competitive advantage and is believed to be able to create value added which affect the company's financial performance improvement (Dadashinasab \& Sofian, 2014).

\section{Intellectual capital}

Intellectual capital is considered as an asset-based knowledge in the company that became the basis of company's core competencies that can affect the development of durability and excellence of companies (Michael, 2001), while Valentine (2002) intellectual capital is the result of the transformation process or knowledge itself, which is transformed into a valuable asset for the company.

\section{Value added human capital}

Human capital is the ability of the member companies that using in the process of creation of the company's intellectual assets. Human capital is reflected in four dimensions: education and training, experience, competence, and commitment (Sangkala, 2006). Human capital is also a key factor to support and create value over time (Alipour, 2012).

\section{Structural capital}

Structural capital is an ability that is in the company to meet the routine and structure associated with employee efforts to produce intellectual performance of companies to be optimal as well as the performance of the company's business as a whole, for example: systems operations, manufacturing processes, organizational culture, management philosophy, and all forms of intellectual property owned by the company. An individual who has intellectual quality, but the operating system and procedures of the company is bad, then the intellectual capital can not achieve optimal performance and potential can not be fully utilized (Sawarjuwono \& Kadir, 2003)

\section{Capital employee}

Capital employee demonstrate a balanced relationship between the company and its partners, both from a reliable and qualified suppliers, customers loyal and satisfied with the service companies, as well as the company's relationship with the government and the communities (Riahi \& Belkaoui, 2003).

\section{Value added intellectual capital}

Value added intellectual coefficient was developed by Pulic (2008), designed to provide information on the value creation efficiency of tangible and intangible assets owned by the company. This model starts with the company's ability to create value added (VA). The main components of VAIC developed by Pulic (2008) can be seen on the company's resources, capital employee (VACA), 
human capital (VAHU) and structural capital (STVA).

\section{Return on asset}

Return on assets (ROA) reflect business benefits and efficiency in the utilization of total assets (Chen et al., 2005). This ratio is a profitability ratio that measures a company's ability to generate profits in using the company's total assets. ROA is obtained by dividing net income by the total company. The higher the ROA, it means that the company can generate greater revenue, but with a smaller investment.

\section{Return on equity}

Return on equity (ROE) presented the return of capital to holders of ordinary shares, and is generally regarded as one of the important financial indicator for investors (Chen et al., 2005). ROE is obtained by dividing net income by shareholders' equity. The greater the value of ROE, the return of capital to the shareholders to be great, and of course this will attract investors to further invest in the company.

\section{Growth in revenue}

Growth in revenue (GR) is used to measure how fast growing companies. GR shows the rate of increase or decrease in the company's earnings or sales growth, thus the investor gets an idea of how much revenue the company increased from year to year (Chen et al., 2005). Improved corporate earnings show that companies can manage intellectual capital well.

\section{Economic value added}

According Dwitayanti (2005) economic value added (EVA) is a financial management system that measures of economic profit in a company, which states that prosperity can be created if the company is able to meet all operating costs and capital costs. Measurement of the EVA is to reduce operating profit after tax cost of capital (cost of capital) where the burden of the cost of capital reflects the company's risk level.

\section{Hypotesis Development}

\section{Intellectual capital on financial performance}

Subhkan \& Citraningrum (2010) examined the effect of intellectual capital on the financial performance of the company. Research result shows that intellectual capital (IC) with financial performance has a significant positive effect on the financial performance perusahaan.

Gan and Saleh (2008) examined the relationship between intellectual capital and firm performance. They found that intellectual capital has a significant impact on profitability and also the company's productivity. Chen et al., (2005) used the same method find results that affect the profitability intellectual capital. In Indonesia research of intellectual capital that do Ulum et al., (2008) showing that intellectual capital significantly influence the financial performance of the banking company. Subhkan and Citraningrum (2010) using the same method showed that intellectual capital has a significant impact on the financial performance of the company.

The hypothesis of this study are as follows:

H1a: Value added intellectual coefficient (VAIC) effect on financial performance.

H1b: Value added capital employed (VACA) effect on financial performance.

H1c: Value added human capital (VAHU) effect on financial performance.

H1d: Structural capital value added (STVA) effect on financial performance.

As was mentioned above that this study involves three steps VAIC components: value added capital employed (VACA), value added human capital (VAHU), structural capital value added (STVA). Different significance can be put on the individual components of VAIC, thus attracting researchers tested the effects of the individual components of VAIC the financial performance indicators.

\section{Research Methods}

This study will examine the effect of intellectual capital and their respective components of financial performance. This study uses a quantitative approach, to test the hypothesis using multiple linear regression analysis. Analysis model used in this study are:

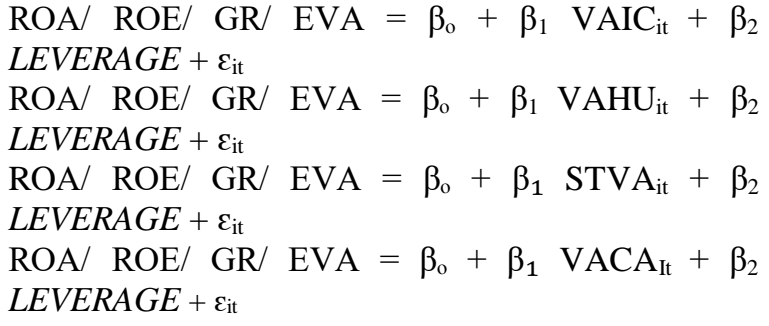




\section{Population and sample}

In the sample selection using purposive sampling the researcher to look at companies that have a complete variable to be investigated, The final sample of this study consisted of 51 companies listed on the Indonesian Stock Exchange (BEI). Period 2010-2014 research in this study that the number of samples multiplied by 5 years amounted to 255 . This study uses quantitative data, the data derived from the annual financial statements obtained from the manufacturing company official website of Indonesia Stock Exchange (BEI) www.idx.co.id.

Criteria for selection of samples in this study were: (1) companies listed on the Stock Exchange in 2010-2014. (2) Companies that have positive earnings. (3) companies that have positive equity. (4) the company has no data are outliers. (5) companies with complete financial statement during the study period. (6) companies are using rupiah currency.

\begin{tabular}{clc}
\cline { 2 - 3 } No. & \multicolumn{1}{c}{ Expalantion } & $\begin{array}{c}\text { Company } \\
\text { Quantity }\end{array}$ \\
\cline { 2 - 3 } 1 & $\begin{array}{l}\text { companies listed on the } \\
\text { Stock Exchange in 2010- } \\
2014 . \text { 6mies that have } \\
\text { companies } \\
\text { negative earnings } \\
\text { companies that have } \\
\text { negative equity } \\
\text { the company has data are } \\
\text { outliers } \\
\text { companies with complete } \\
\text { financial statement during } \\
\text { the study period } \\
\text { companies are using } \\
\text { foreign currency }\end{array}$ \\
\hline 7 & total sample of companies \\
\hline
\end{tabular}

\section{Variable and measurement research}

\section{Independent Variable}

This study includes four independent variables Pulic (2008): First, value added human capital (VAHU). Second, structural capital value added (STVA). Third, value added capital employed (VACA). Fourth, value added intellectual coefficient (VAIC) which is the result of a combination of three separate indicators. In the first step prior to the above variables is to calculate::
1. Value added (VA)

$$
\text { VA = Output - Input }
$$

2. Value added capital employed (VACA)

VACA $=$ VA / CF

a. $\mathrm{VA}=$ Laba operasi - Biaya karyawan

b. $\mathrm{CE}=$ Total asset - total kewajiban

3. Value added human capital (VAHU)

$$
\mathrm{VAHU}=\mathrm{VA} / \mathrm{HC}
$$

a. $\mathrm{HC}=$ Biaya karyawan

4. Structural capital value added (STVA)

$$
\text { STVA = SC / VA }
$$

a. $\mathrm{SC}=\mathrm{VA}-\mathrm{HC}$

5. Value added intellectual coefficient (VAIC)

$$
\text { VAIC }=\text { VACA }+ \text { VAHU }+ \text { STVA }
$$

\section{Dependent Variable}

This study covers the dependent variable is the company's financial performance. Financial performance here is measured using four indicators:

$$
\mathrm{ROA}=\frac{\text { net income after } \text { tax }}{\text { total asset }}
$$

$\mathrm{ROE}=\frac{\text { net income after tax }}{\text { total equity }}$

$\mathrm{GR}=\frac{\text { revenue } t-\text { revenue } t-1}{\text { revenue } t-1}$

$\mathrm{EVA}=$ Nopat $-($ wacc $/$ invested capital $)$

Return on assets is the company's ability to generate profits by using its assets, return on equity is the company's ability to generate profits in the use of capital either from its own capital and capital from shareholders. growth in revenue shows the revenue growth in a company. Economic value added shows how much the company is Able to prosper seen from the company's refund rate.

\section{.Variable control}

This study using leverage as a control variable, leverage reflects a company's ability to finance its assets using calculation debt with leverage $=$ total assets / total debt.

\section{Result}

\section{Statistic description}


Table below presents the descriptive statistics for all variables used in the study. As shown in Table 1 the average (mean) value added intellectual coefficient (VAIC) is 4.16 and the standard deviation is 2.09, value added human capital (VAHU) with an average (mean) value of 3.38 the highest average among the other components of VAIC and economic value added (EVA) indicators with an average (mean) 24.06 has the highest average value among other financial performance indicators.

\begin{tabular}{|c|c|c|c|c|}
\hline Variable & Min & $\operatorname{Max}$ & Mean & std.deviation \\
\hline ROA & 0.00 & 1.25 & 0.12 & 0.13 \\
\hline ROE & 0.00 & 3.23 & 0.22 & 0.36 \\
\hline GR & -0.35 & 3.48 & 0.16 & 0.28 \\
\hline EVA & 18.65 & 31.84 & 24.06 & 2.28 \\
\hline VAHU & 1.01 & 11.29 & 3.38 & 1.87 \\
\hline STVA & 0.01 & 0.91 & 0.60 & 0.22 \\
\hline VACA & 0.00 & 0.86 & 0.18 & 0.14 \\
\hline VAIC & 1.08 & 12.93 & 4.16 & 2.10 \\
\hline LEVERAGE & 0.05 & 3.40 & 0.42 & 0.26 \\
\hline SAMPEL & 255 & & & \\
\hline
\end{tabular}

\section{Hypothesis testing}

\begin{tabular}{lllll}
\hline & ROA & ROE & GR & EVA \\
\hline VAIC & $\mathbf{0 . 0 0}$ & $\mathbf{0 . 0 0}$ & $\mathbf{0 . 0 0}$ & $\mathbf{0 . 0 0}$ \\
VAHU & $\mathbf{0 . 0 0}$ & $\mathbf{0 . 0 0}$ & $\mathbf{0 . 0 0}$ & $\mathbf{0 . 0 0}$ \\
STVA & $\mathbf{0 . 0 0}$ & $\mathbf{0 . 0 0}$ & $\mathbf{0 . 0 0}$ & $\mathbf{0 . 0 0}$ \\
VACA & $\mathbf{0 . 0 0}$ & $\mathbf{0 . 0 0}$ & $\mathbf{0 . 4 6}$ & $\mathbf{0 . 1 1}$ \\
\hline
\end{tabular}

Table above presents the results of H1a-H1d, the results show that the value added intellectual coefficient (VAIC), value added human capital (VAHU), structural capital velue added (STVA) significantly affects the fourth indicator of financial performance (ROA, ROE, GR, EVA), because all the coefficients are statistically significant probability value 0,00 which is located at the 0.01 level, therefore H1a-H1c supported by empirical data. The results in Table 2 also shows that the value adde capital employed (VACA) significantly affects two indicators of financial performance (ROA, ROE), because statistically significant coefficient 0,00 probability values are at significant in level 0.01 percent. Therefore H1d on ROA and ROE financial performance supported by empirical data. But for value added capital employed (VACA) no significant effect on the financial performance indicators are GR and EVA, since the probability values of 0.48 and
0.11 shows that have a value of more than three significant level used in this study, so H1d on GR's financial performance and EVA is not supported by empirical data.

\section{Conclusion}

Based on the analysis and discussion of the results to test hypotheses using panel data regression analysis, conclusions can be drawn. Intellectual capital affect the financial performance as measured by return on assets (ROA), return on equity (ROE), growth in revenue (GR) and economic value added (EVA). This shows that the companies listed on the Indonesian Stock Exchange (BEI) has used efficiently use of available resources (VAHU, STVA, VACA) so as to improve the financial performance of the company.

Human capital effect on financial performance as measured by return on assets (ROA), return on equity (ROE), growth in revenue (GR) and ecomic value added (EVA). This shows that the company has succeeded in meeting the needs of employees such as salary, benefits as well as providing training, so that employees are motivated to produce optimal productivity and will increase the company's financial performance.

Structural capital affect the financial performance as measured by return on assets (ROA), return on equity (ROE), growth in revenue (GR) and economic value added (EVA). This indicates that the structure provided in the companies listed on the Stock Exchange has been managed well so that it can help the performance of human capital in the conduct of business performance that can efficiently time impact on improving financial performance.

Capital employee influence on financial performance as measured by return on assets (ROA) and return on equity (ROE). But capital does not affect the employee's financial performance as measured by growth in revenue (GR) and economic value added (EVA). This means that the companies listed on the Indonesian Stock Exchange (BEI) has not been able to take advantage of physical capital owned optimally.

This study has limitations that can be considered for further research in order to obtain better results again. First, this study only used data manufacturing company. Second, measurement IC are used in research only using measurement models VAIC pulic (2008). Third, the financial performance 
measurement study was only using measurements ROA, ROE, GR and EVA. For further research is recommended to add or try another measuring intellectual capital, in addition further research is also expected to use the data company whose business is driven by knowledge and information because it shows that the IC has a very important role in the company. Companies engaged in the service sector or banking worth a try to see the IC in the banking company. Researchers then can add or change any other measurement of financial performance which in terms of the profitability ratio that can be measured by the gross profit margin and net profit margin, it demonstrates the company's ability to generate profits.

\section{Reference}

Alipour, M. (2012). The Effect of Intellectual Capital on Frm Performance: an Investigation of Iran Insurance Companies. Measuring Business Excellence.

Chen, M., Cheng, S., \& Hwang, Y. (2005). An Empirical Investigation of The Relationship Between Intellectual and Firm's Market Value and Financial Performance. journal of intellectual capital Vol. ,6 No 2., 159-176.

Dadashinasab, M., \& Sofian, S. (2014). The Impact of Intellectual Capital on Firm Financial Performance by Moderating of Dynamic Capability. Asian Social Science, 95.

Dwitayenti, Y. (2005). Analisis Pengaruh Economic Value Added Terhadap Market Value Added Pada Industri Manufaktur di Bursa Efek Jakarta”. Jurnal Manajemen Keuangan Vol.3 No.1, 59-73.

Edvinsson, L., Malone, M.S. (1997), Intellectual Capital: Realizing Your Company's True Value by Finding Its Hidden Brainpower, Harper Business, New York, NY, .

Gan, K., Saleh, Z. (2008), "Intellectual capital and corporate performance of technology-intensive companies: Malaysia evidence", Asian Journal of Business and Accounting, Vol. 1 No.1, pp.113-30.
Guthrie, \& James. (2001). The Management, Measurement and Reporting of Intellectual Capital . Journal of Intellectual Capital. Vol.2, , 31.

Michael. (2001). Mapping Intellectual Capital in A Small Manufacturing Enterprise. Journal of Intellectual Capital, 53.

Nahapiet, \& Ghosal. (2002). Strategic Mangement of Intellectual capital dan Organizational Knowledge.

Pulic, A. (2008). The Principles of Intellectual Capital Efficiency - A Brief Description. Croation Intellectual Capital Center, 1-21.

Riahi, \& Belkaoiu. (2003). Intellectual Capital and Firm Performance of US Multinational Firms: Study of the Resource Based and Stakeholder Views. Journal of Intellectual Capital Vol. 4. No. 2., 215-226.

Sangkala. (2006). Intellectual Capital Management: Strategi Baru Membangun Daya Saing. Yogyakarta: YAPENSI.

Sawarjuwono, T., \& Kadir, A. (2003). Intellectual Capital : Perlakuan, Pengukuran, dan Pelaporan (Sebuah Library Research). jurnal akuntansi \& keuangan Vol. 5, No.1, 35-57.

Subkhan, \& Citraningrum, P. (2010). Pengaruh IC Terhadap Kinerja Keuangan Perusahaan Perbankan Periode 2005-2007. Jurnal Dinamika Akuntansi Vol. 2, No 1, 30-36.

Valentine, M. (2002). Intellectual Capital: Managerial Perception of Organizational Knowladge. Journal of Intellectual Capital Vol. 3. No.2., 149-146.

Wijayanti. (2012). Pengaruh Intellectual Capital Terhadap Harga Saham Melalui Kinerja Keuangan Pada Perusahaan Perbankan Yang Terdaftar Di Bursa Efek Indonesia (Bei) Pada Tahun 2009-2011. 